\title{
Towards a culturally responsive and place-conscious theory of
} history teaching

\section{MICHAEL HARCOURT}

\section{KEY POINTS}

- To address educational inequality, history teachers cannot rely solely on the general characteristics of culturally responsive pedagogy, but should combine them with approaches grounded in research specific to their discipline.

- Culturally responsive history teachers should be aware of the ways in which racism and other forms of prejudice are sometimes expressed specifically in the subject of history.

- $\quad$ Place-based education can help history teachers practise a culturally responsive pedagogy grounded in the unique historical, cultural, and ecological contexts in which their students live and learn. 
Many teachers are familiar with the characteristics of culturally responsive pedagogy, which include an ethic of care based on deep relations underlying all classroom interactions, power sharing between students and teachers, challenging deficit theories of achievement, and making students' cultural and ethnic identities and knowledge fundamental dimensions to curriculum design. These ideas make classrooms more inclusive and challenge teaching practices and mindsets that disadvantage some learners, especially Māori and Pasifika. This article proposes that history teachers supplement the general characteristics of culturally responsive pedagogy with principles specific to the disciplinary conventions of their subject. Additionally, teachers need to draw on place-based education to respond to their students' unique historical, cultural and ecological contexts. I propose five principles that together help history teachers enact a culturally responsive and placeconscious theory of history teaching.

\section{Introduction}

I recently attended a conference session that was not only about culturally responsive pedagogy, but also modelled some of its key characteristics. Unlike the traditional conference format, in this session the presenters welcomed each of us individually into the room. We moved the chairs into a circle and talked with the people beside us about where we were from, who we were, and why we had chosen to be present at that session. Someone summarised so the whole group had a sense of each person's story. The presenters then spoke, at various times asking for our contributions. At one point someone left the room in a coughing fit and one of the presenters went out to check on her, coming back and exclaiming, "we can't have one of the community dying on us!" No one in that session could hide at the back of the room checking emails. Everyone was made to participate, and made to feel like they were part of a community.

The characteristics of culturally responsive pedagogy include, but are not limited to: an ethic of care based on deep relations underlying all classroom interactions; power sharing between students and teachers; challenging deficit theories of achievement by maintaining the highest expectations of every learner; and making students' cultural and ethnic identities and knowledge fundamental dimensions of curriculum design (Berryman, M., SooHoo, S., \& Nevin, 2013; Bishop \& Berryman, 2006; Gay, 2000;
Ladson-Billings, I995). Culturally responsive pedagogy attempts to address the fact that schools tend to serve some students much more effectively than others (NZQA, 20I3). In New Zealand, culturally responsive pedagogy challenges teaching practices, mindsets, and school traditions that alienate Māori, Pasifika, and other ethnic minorities from formal education, or that create a sense of cultural discontinuity between school and home (Ford, 20I3; Hynds et al., 20II; Reymer, 20I2). While culturally responsive pedagogy benefits all students, it is particularly important for the educational achievement of those who do not identify closely with the dominant cultural or ethnic group.

Culturally responsive pedagogy offers every New Zealand teacher a powerful framework to draw on to make education more equitable. However, its generic nature has some weaknesses. The kinds of pedagogical features described above can be applied equally effectively in a mathematics, science, or history class. A practising classroom history teacher, I have engaged with the literature of culturally responsive pedagogy, and have been involved in He Kākano, and Kia Eke Panuku: Building on Success, both of which draw heavily on the ideas of an earlier project, $\mathrm{Te}$ Kōtahitanga. Despite benefiting from this engagement, I have not encountered ideas that could directly help me enact culturally responsive pedagogy in a manner particular to my subject and its unique disciplinary conventions. In addition, I consider that culturally responsive pedagogy may not adequately highlight how 
racism and other forms of prejudice can become manifest specifically in my subject. Finally, I have come to see as a key weakness the fact that culturally responsive pedagogy does not explore in depth the unique historical, cultural and ecological contexts in which students live and learn. Therefore, a culturally responsive, place-conscious theory of history teaching supplements the general characteristics of culturally responsive pedagogy with ideas and approaches relevant to history teachers, the nature and content of their subject, and the specific geographic location of their school communities.

In this article I suggest five principles drawn primarily from history education research. They aim to help teachers to more actively and effectively create the kinds of learning environments needed for all students to achieve. I do not claim that they are comprehensive, and certainly do not suggest they come at the expense of mainstream approaches to culturally responsive pedagogy. However, they may provide a lever for deeper conversations about what culturally responsive history teaching — at all levels of the curriculum — might look like in a New Zealand context. The principles are as follows.

- Recognise the identities and interpretive frameworks of students and teachers.

- Actively confront controversial history.

- Connect the past to students' lived realities.

- Recognise and evaluate historical agency.

- Be responsive to place.

\section{Five principles of culturally responsive history teaching}

\section{Recognise the identities and interpretive frameworks of students and teachers}

Teachers who know about their students' ethnic, gender, class, or religious identities are in a better position to help them grapple with contested accounts of the past (Peck, 20IO). However, teachers need to pay special attention to ethnic identity owing to its strong influence on students' sense of self (Howard, 2004; Webber, 2012, 2013). This requires history teachers to be confident with "[raising] gritty questions about how their students relate to their own ethnicities and those of others" (Webber, 2013, p. 67). Peck (2012) contends that paying attention to the relationship between a student's ethnic identity and the learning of history can open up opportunities to investigate why diverse societies have different and competing ideas about historical significance (pp. 609-6ro). One of Peck's studies shows that Canadian students' ethnic identities influenced how they attributed significance to particular historical events as well as the kind of historical narratives they used to make meaning out of Canada's national history (Peck, 2012, p. 607). She calls for teachers to help students "identify and explore the reasons why they are drawn to particular [narratives], and which narratives they take for granted as the status quo" (2012, p. 6ro). Peck also notes that "if dominant narratives are reproduced, students can begin to explore reasons why certain narratives are dominant and others are marginalized. Do other students understand Canadian history in the same way? If not, why not? What is the nature of the differences in understandings?" (2012, p. 6ro). Exploring these kinds of questions in relation to ethnic identity may help students to more critically interrogate the ways that historical power relations leave traces in the present, shaping the way people think and relate to each other today.

Culturally responsive history teachers are also attuned to the interpretive frameworks that shape their own understanding of the past. An interpretive framework is the "web of beliefs and knowledge" that teachers use to shape their personal understanding of history's trajectory and the role of individuals and groups within it (Epstein, 2009, p. 3). The consequences of not interrogating these frameworks are that students may feel excluded and sometimes even humiliated (Traille, 2007). In a study exploring the differences between black and white students' experiences of learning history in schools, Epstein found white teachers routinely dismissed black students' contributions. For example, one teacher often asked for students' input but "only acknowledged suggestions that fit into his preconceived ideas about what was significant in black history or what he felt comfortable discussing" (Epstein, 2009, p. 56). Other teachers in this study found it difficult to affirm black students' family knowledge of history, especially when it related to the violent past. They also tended to emphasise racial cooperation and "conceptualized racism as a tragic yet sporadic problem which became less problematic as the nation developed" (Epstein, 2009, p. 59). Epstein's work underscores the importance of all teachers being alert to their cultural positioning and the assumptions that might shape their own historical understanding and, consequently, the learning experiences of students.

\section{Actively confront controversial history}

History teachers need to intentionally explore the controversy and emotion associated with aspects of $\mathrm{New}$ Zealand's history, because suppressing the controversial, "difficult" past may validate contemporary arrangements of power and privilege (Levstik, 2000; Trouillot, 1995). Early in my career, I spoke with a teacher who avoided teaching the Treaty of Waitangi because she deemed it too controversial for the teacher's group of middle- 
class, Pākehā students who did not want to know about "Māori history". The teacher feared that learning about the Treaty would only solidify students' ignorant and sometimes overtly racist views. This anecdote illustrates an understandable fear, and is certainly one that I can empathise with. However, excluding students from learning about an aspect of New Zealand's history on this basis does not give them an opportunity to engage in a very real contemporary topic, its connection to the past, and its implications for the future. Instead it likely validates the belief that "Māori history" is less significant than other history. Furthermore, whether or not they personally want to, privileged students need to explore diverse-and in this case controversial-history to "help counter assumptions that they are the 'natural' leaders of society, that their concerns are universal ones, or that others' perspectives amount to a form of identity politics or special form of pleading" (Barton, 20I2, p. I33). This quotation also highlights the importance of a culturally responsive history programme subjecting to critical analysis historical racism, its individual and institutionalised nature, the way it has privileged white people, and its legacy today.

The example above of a teacher avoiding controversy may not be an isolated case. Social studies and history teachers in New Zealand and internationally have been critiqued for avoiding or simplifying topics that might generate controversy (Epstein, 2009; Keown, I998; Levstik, 200o; Otago Daily Times, 2010; Wood, 2007; Wrenn, 2007). Why teachers often distance themselves from controversial issues is complex, but one reason, as the example above illustrates, is due to their legitimate fear of unleashing an emotive response that will only harden students' existing positions. In fact, Kitson and McCully (2005) argue that teaching controversial issues can have exactly this effect. However, they claim that this is "precisely because teachers [did] not [ask] students to confront the impact their own contemporary positions might [have] on their historical thinking" (p.36).

Therefore, culturally responsive history teachers need to be active in exploring with students how, why, and at what emotional level they respond to controversial aspects of history, paying particular attention to the differences within the class and in students' communities.

\section{Connect the past to students' lived realities}

Culturally responsive history teachers consciously and consistently connect students' lived experiences, emotions, beliefs, family history, and tacit understandings to the content of the curriculum (Barton \& McCully, 2007; Kitson \& McCully, 2005; Taumua, 20I4).
As McCully (20I0) argues, "unless young people are encouraged to recognize the impact their lived experiences ... may have on the way they see the past, they are unlikely to overcome those emotional barriers that inhibit critical understanding" (p. 178). In an important piece of classroom-based research, New Zealand history teacher Christine Reymer explored the ways in which her students' Pasifika identities and cultural understandings shaped the way they experienced the history curriculum (2012). Arguing that "the dominant Pākehā culture found in many New Zealand schools is in many ways at odds with the cultural values of the students in my research" (p. 6o), Reymer revealed a potential tension between her students' identities and cultural values and the curriculum's commitment to critical historical thinking. She demonstrated that the lived cultural realities of Pasifika students were not an obstacle for teachers to overcome. Instead, they were a resource to be valued and could help develop and legitimate students' Pasifika identities as well as their critical engagement with the discipline of history.

Boston teacher Chris Martell tied the themes of United States national history to the diverse histories of each student. For example, his immigrant students wanted to learn about United States history in relation to their home country's concurrent historical situation, and some students wanted more knowledge about how the experiences of their working-class ancestors were similar or different to white immigrants' experiences (Martell, 20I3, pp. 80-8I). In a history class about conflict in Africa, Sheppard (20I0) describes a teacher who had African students report on their experiences of their home country, which was then consolidated by more formal historical analysis. Drawing on students' firsthand experiences and testimony of the events and places under study will not be possible in most New Zealand contexts, but teachers should certainly draw on the historical experiences of their students' families and how these connect to national and global historical themes. History educators Harris, Burn and Woolley (2013) connect this idea to culturally responsive pedagogy when they argue that "if students are unable to see themselves reflected in the curriculum, it can seem less meaningful and irrelevant and so students feel excluded and become disengaged" (p. I82).

Three further strategies that incorporate students' lived experiences into instruction could include:

- Connect the content to "cultural universals" or the "domains of human experience that have existed in all cultures, past and present" (Alleman, Knighton \& Brophy, cited in Aitken \& Sinnema, 2008, p. 64).

- Ask students about the decisions made by historical actors and what they might have done in a similar 
situation, and then discuss the extent to which their responses might be a product of their contemporary context.

- Ask students what historical actors they personally identify with and track if these change over the course of a unit. Student responses could lead into intellectually rigorous conversations about presentism: the uncritical use of the present to filter perceptions of the past.

\section{Analyse texts for historical agency}

Students familiar with the concept of historical agency are better positioned to challenge the ways in which historically marginalised people are often portrayed as the victims or benefactors of other peoples' actions, rather than as agents who struggled to reform, resist or maintain their situations (Clark, 2007; Clark, 2013, p. 492). Historical agency is a second-order or procedural concept within the discipline of history. Two definitions of agency are:

The relationship between structural forces that shape historical events and the ways people influence, shape, and are affected by these events. That is, human beings are autonomous agents with abilities to affect change, yet there are social structures that constrain and limit what individuals can do. (Damico, Baildon \& Greenstone, 20Io, p. 2)

Agency is about power-how groups, individuals, and institutions establish, maintain, constrain, expand, resist, or lose power (Levstik \& Barton, 20I5, p. 29).

All historical actors, and especially ones that Māori, Pasifika, and other ethnic minorities might personally identify with, need to be "re-framed as agentic individual and collective actors in history and society" (Epstein, Mayorga \& Nelson, 20II, p. 4). New Zealand historian Anne Salmond (2006) reminds history teachers of the importance of this when she argues that "I realized then that history is a power in the present. Ignore the narratives and agency of people in the past, and you are likely to ignore their descendants" (p. 142). Furthermore, Barton and Levstik suggest that students with a complex knowledge of historical agency may "see themselves as historical actors. Just as the actions of people in the past produced history, so too do students' actions today and tomorrow make history" (cited in Damico, Baildon \& Lowenstein, 2008, p. 58). The difficulty for all history teachers is that students quickly absorb the implicit theories of agency from society, theories which frequently marginalise the less powerful. For example, a small-scale classroom study $(N=24)$ by Peck, Poyntz, and Seixas (20II) asked students to spend 40 minutes writing a history of Canada. The transcripts were analysed for how they presented historical agents of change, and the kinds of intentionality those people were shown to have when making decisions. The study found that only one individual, the nineteenth-century politician John MacDonald, was mentioned with any frequency in student accounts. Women received little attention and when they were mentioned, they played only supporting roles. Native Canadians were positioned primarily as the victims of settler power. This study illustrates the strength of implicit theories of agency. It highlights the need for history teachers to investigate and respond to how these theories govern students' understanding of the past. Barton illustrates why it might be problematic to leave implicit theories of historical agency uninterrogated when he writes that "the common 'land-robbing' explanation [for why Māori chiefs and the British Crown signed the Treaty of Waitangi] fails to provide either White or Māori students with a sense of identification. White students are unlikely to identify with ancestors who seem so singlemindedly exploitative, and Māori students may not want to think of their ancestors as lacking in power or agency. Asian, Pasifika, and other groups, meanwhile, are not part of the story at all" (2OI2, p. IOI).

Teachers can introduce students to historical agency by asking them to draw a history of their nation or world and their place in it, and then discuss and compare who the historical actors are and how they have positioned themselves in relation to their diagram (Seixas \& Morton, 20I2, p. 26). Students could also be encouraged to consider or compare representations of historical agency in textbooks, museums, graphic novels, historical films, documentaries or local memorials. Damico (see Figure I) suggests four key questions for teachers to use with students, all of which could be adapted to a range of contexts and activities.

1. What key people/characters, events and issues, and settings/contexts are discussed in the [source]?

2. What role do the main [historical actors] play in bringing about or shaping significant events or issues?

3. How are the [historical actors] affected or shaped by certain contexts or conditions?

4. How are key concepts in history-significance, change and continuity, progress and decline, perspective and judgment-portrayed in terms of agency?

\section{FIGURE 1. QUESTIONS TO CONSIDER WHEN DISCUSSING HISTORICAL AGENCY (adapted from Damico et al., 2010)}

\section{Be responsive to place}

History teachers need to draw on place-based education to help them respond to the unique historical, cultural 
and ecological contexts that shape students' cultural identities (Gruenewald, 2008). Responsiveness to place is especially important for New Zealand history teachers because it allows them to engage in ways of knowing more aligned with Māori approaches to the past (Manning, 2009; Taumua, 2014). New Zealand educationalist Wally Penetito (2009) endorses place-based education from a Māori perspective, arguing that "for indigenous peoples, a sense of place is a fundamental human need" (p. 20). This principle is perhaps the hardest to enact, especially within the confines of common schooling practices that often restrict learning to classrooms, short units of time, and single academic disciplines. It is also different from the previous four principles because it explicitly draws on ideas that do not come from history education or the disciplinary conventions of the subject.

A basic definition of place-based education is "using places, environments, and communities (mainly those nearby but also those far away) as living contexts for experience and curriculum development and enrichment" (Greenwood, 20II, p. 632). Proponents of place-based education argue that educators need to be responsive to places "so that the education of citizens might have some direct bearing on the well-being of the social and ecological places people actually inhabit" (Gruenewald, 2003, p. 4). Gruenewald suggests this can be done through the twin goals of reinhabitation and decolonisation. Briefly, reinhabitation means "learning to live-in-place in an area that has been disrupted and injured through past exploitation" (Berg \& Dasmann, cited in Gruenewald, 2003, p. 9). Decolonisation on the other hand, "involves learning to recognize disruption and injury and to address their causes" (Gruenewald, 2003, p. 9). Decolonisation also involves "addressing the history of colonization from Indigenous perspectives, deconstructing structures from the past and in the present associated with settler colonialism, and considering a different future with reference (and relevance) to the imperatives of Indigenous peoples" (McGregor, 2013).

Scherff and Spector (2010) argue that the relationship between culturally responsive pedagogy and placebased education is one of emphasis claiming that "CRP [culturally responsive pedagogy] strives to use learners' cultural ways of being and knowing as a vehicle for instruction as well as a source of content, while placebased learning takes as its starting point the varying contexts from which learners come" (p. I4I). Other theorists critique culturally responsive pedagogy on the basis that it makes the concept of culture too abstract and that it does not adequately acknowledge students' ecological embeddedness and "all the diverse ecological places that make possible any cultural formation, any identity, and any idea" (Gruenewald, 2008, p.I44). While not rejecting the social justice goals of culturally responsive pedagogy, Gruenewald (2008) argues that:

place conscious educators propose a different but related focus for educational attention and cultural responsiveness: cultural/ecological places common to the lived experiences of learners... a focus on the lived experience of place puts culture in context, demonstrates the interconnection of culture and environment, and provides a locally relevant pathway for multi-disciplinary inquiry and democratic participation ( p.I48).

Some key challenges for place-conscious history teachers are the interdisciplinary requirements of place-based education, its support for participatory action and its commitment to developing curriculum that "emerges from the particular attributes of a place" (Penetito, 2009, p. 7). History teachers often think of the past and historical forces in the abstract. The cultural, historical and ecological embeddedness of the communities in which teachers work have tended to play no major role in what and how the past is taught (Manning, 2008, 2009). An additional challenge, and one that many New Zealand teachers will recognise, is that students can actively resist learning anything about New Zealand history, let alone about the history of the places directly beneath their feet (Levstik, 20oI, p. 87). Greenwood (2OII) suggests that history can contribute to the goals of place-based education by posing the crucial question "what happened here?" claiming that "not to know the past of where one's present unfolds seems to me the most profound cultural negligence, yet this is an everyday act committed by most history texts and most schools" (p. 638). This comment has particular resonance when teaching Māori history. Being responsive to place in this context means that teachers "engage with local iwi to codevelop culturally responsive courses that [address] the whakapapa of local iwi in authentic contexts" (Manning, 2008, p. 54). Resources such as Tàtaiko: Cultural Competencies for Teachers of Māori Learners (Ministry of Education, 2OII) and Te Takanga o te Wā-Màori History in Aotearoa New Zealand (Tamua, 20I4) and the clusters of teachers working on the Ministry of Education's Māori history project (see http://www.beehive.govt.nz/ release $/ \mathrm{m} \% \mathrm{C}_{4} \% 8$ Iori-history-school-curriculum), all point to important support and progress in this direction.

Below are three brief illustrations of how history education can be responsive to place:

- Te Âtiawa people interviewed by Manning suggest that teachers treat the Treaty of Waitangi not as an event that took place far away in Northland, but as a local event that connects to local families, experiences, and historical contexts (2008, p.134).

- Wessels (1997) teaches students how to use the hidden clues embedded within the landscape of local forests 
as evidence of historical environmental change and the relationship between the human and more-than-human worlds.

- Students in Montclair, New Jersey, carried out an oral history project in their local community. Students interviewed local community members about the history of desegregation in their area and how it connected to the national Civil Rights Movement. The class worked with a nearby university to publish a book about their findings (Anand et al, 2002).

\section{A key challenge for history teachers}

Enacting a culturally responsive and place-conscious history curriculum as outlined above is no easy task, especially in the often solitary and always busy world of teaching. It requires deep familiarity with the general features of culturally responsive pedagogy, history education research, and local places. In fact, deep familiarity with these sources is not enough. It also requires a dispositional shift, an "agentic positioning" that puts a key part of the solution to New Zealand's failing education system firmly in the hands of teachers. It was not until my involvement with He Kākano and Kia Eke Panuku: Building on Success that I could see my own complicity in a system that continually fails some students. History teachers must face the uncomfortable truth that schools "perpetuate images of children in ways that are destructive, in ways that predispose some children to be successful, confident, and engaged, and others to become lower achieving, timid or aggressive, reluctant and disengaged" (Shields, Bishop \& Mazawi, 2004, p. I). Additionally, place-based education challenges teachers to consider the nature and purpose of their history programmes and how history teaching might contribute to the twin educational goals of reinhabitation and decolonisation.

\section{Conclusion}

Teachers need to theorise their work according to the needs of New Zealand's most vulnerable students and their communities. Without such theory-driven practice they are more likely to inadvertently contribute to a system and society that disadvantages some learners. This article is intended as a "thought piece" to support teachers to theorise their practice more deeply and enact culturally responsive curriculum in ways unique to their discipline. As stated earlier, the principles are incomplete. However, I hope they promote a conversation about what culturally responsive pedagogy might actually look like in history classrooms. Teachers engaged in such a conversation are powerfully positioned to change, not merely replicate, the current disparities in education.

\section{Acknowledgements}

The author would like to acknowledge Professor Terrie Epstein, of Hunter College at the City University of New York for her support and input with this article. $\mathrm{He}$ would also like to thank Fulbright New Zealand and the Cognition Institute, whose award in 2015 made this paper possible.

\section{References}

Aitken, G., \& Sinnema, C. (2008). Effective pedagogy in social sciences/tikanga-a-iwi: Best evidence synthesis iteration [BES]. Wellington: Ministry of Education.

Anand, B., Fine, M., Perkins, T., \& Surrey, D. (2002). Keeping the struggle alive: Studying desegregation in our town: A guide to doing oral history. New York, NY: Teachers College Press.

Barton, K.C. \& Levstik, L. (2004). Teaching history for the common good. Mahwah, NJ: Lawrence Erlbaum Associates.

Barton, K.C., \& McCully, A. (2007). Teaching controversial issues ... where controversial issues really matter. Teaching History, I27, I3-19.

Barton, K.C. (20I2). School history as a resource for constructing identities: Implications of research from the United States, Northern Ireland, and New Zealand. In M. Carretero, M. Anensio \& M. Rodriguez-Moneo (Eds.), History education and the construction of identities (pp. 93-107). Charlotte, NC: Information Age Publishing.

Barton, K.C. (20I2). Agency, choice and historical action: How history teaching can help students think about democratic decision making. Citizenship Teaching and Learning, 7, I3I-I42. http://dx.doi.org/IO.I386/ctl.7.2.I3I_I

Berryman, M., SooHoo, S., \& Nevin, A. (Eds.). (2013). Culturally responsive methodologies. Bingley, United Kingdom: Emerald Publishing Group.

Bishop, R., \& Berryman, M. (2006). Culture speaks: Cultural relationships and classroom learning. Wellington: Huia Publishers.

Clark, J.S. (2013). Encounters with historical agency: The value of nonfiction graphic novels in the history classroom. The History Teacher, 46(4), 489-508.

Clark, P. (2007). Representations of Aboriginal Peoples in English Canadian history textbooks: Toward reconciliation. In E. Cole (Ed.), Teaching the violent past: History education and reconciliation (pp. 8I-I20). Lanham, MD: Rowman \& Littlefield and Carnegie Council for Ethics in International Affairs.

Damico, J., Baildon, M., Lowenstein, K. (2008). Did the bombs just fall from the sky? Examining agency in a text set of World War II children's literature. Social Studies Research and Practice, 3(3), 5I-59.

Damico, J., Baildon, M., \& Greenstone, D. (20I0). Cultivating children's agency as readers by examining how historical agency works in children's literature. Social Studies Research and Practice, 5(I), $\mathrm{I}-\mathrm{I} 2$. 
Epstein, T. (2009). Interpreting national history: Race, identity, and pedagogy in classrooms and communities. New York, NY: Routledge.

Epstein, T., Mayorga, E., \& Nelson, J. (20II). Teaching about race in an urban history class: The effects of culturally responsive teaching. The Journal of Social Studies Research, 35(I), 2-2I.

Ford, T. (20I3). Applying culturally responsive practices: Implications for mainstream education. Waikato Journal of Education, I8(2), 25-36. http://dx.doi.org/I0.I5663/wje.vi8i2.I59

Gay, G. (2010). Culturally responsive teaching: Theory, research, and practice. New York, NY: Teachers College Press.

Gruenewald, D. (2003). The best of both worlds: A critical pedagogy of place. Educational Researcher, 32(4), 3-I2. http:// dx.doi.org/I0.3102/00I3189X032004003

Gruenewald, D. (2008). Place-based education: Grounding culturally responsive teaching in geographical diversity. In D. Gruenewald \& G. Smith (Eds.), Place-based education in the global age: Local diversity (pp. 137-153). Mahwah, NJ: Lawrence Erlbaum Associates.

Greenwood, D. (20II). Why place matters: Environment, culture, and education. In S. Tozer, B. P. Gallegos, A. Henry, M. Greiner \& P. Groves-Price (Eds.), Handbook of research in the social foundations of education (pp. 632-640). New York, NY: Routledge.

Harris, H., Burn, K., \& Woolley, M. (2013). The guided reader to teaching and learning history. Abingdon, England: Routledge.

Howard, T. (2004). "Does race really matter?" Secondary students' constructions of racial dialogue in the social studies. Theory \& Research in Social Education, 32(4), 484-502. http:// dx.doi.org/Io.IO80/00933104.2004.10473266

Hynds, A., Sleeter, C., Hindle, R., Savage, C., Penetito, W., \& Meyer, L. H. (20II). Te Kotahitanga: A case study of a repositioning approach to teacher professional development for culturally responsive pedagogies. Asia-Pacific Journal of Teacher Education, 39(4), 339-351. http://dx.doi.org/I0.1080/135 9866X.2011.614684

Kitson, A., \& McCully, A. (2005). "You hear about it for real in school." Avoiding, containing and risk-taking in the history classroom. Teaching History, I20, 32-37.

Ladson-Billings, G. (1995). Toward a theory of culturally relevant pedagogy. American Educational Research Journal, (32)3, 46549I. http://dx.doi.org/10.3102/00028312032003465

Lee, P. (1992). History in schools: Aims, purposes and approaches-A reply to John White. In P. Lee, J. Slater, P. Walsh \& J. White, the aims of school history: The national curriculum and beyond (pp. 20-34). London, England: Tufnell Press.

Levstik, L. S. (2000). Articulating the silences: Teachers' and adolescents' conceptions of historical significance. In P. Stearns, P. Seixas, \& S. Wineburg (Eds.), Knowing, Teaching, \& Learning, History (pp. 284-305). New York: NYU Press.

Levstik, L.S. (200I). Crossing the empty spaces: Perspective taking in New Zealand adolescents' understanding of national history. In O.L. Davis Jr., E.A. Yeager, \& S.J. Foster (Eds.), Historical empathy and perspective taking in the social studies (pp. 69-96). Oxford, England: Rowman \& Littlefield.

Levstik, L. \& Barton, K. (20I5). Doing history: Investigating with children in elementary and middle schools ( 5 th ed.). New York, NY: Routledge.

Manning, R.F. (2009). The status of Te Ātiawa histories of place in Port Nicholson Block (Wellington/Hutt Valley) secondary schools: Some research findings. Curriculum Matters, 5, 5-24.

Manning, R.F. (2008). Place, power and pedagogy: A critical analysis of the status of Te Atiawa histories of place in Port Nicholson Block secondary schools and the possible application of place-based education models. Unpublished doctoral thesis, Victoria University of Wellington.

Martell, C. (2OI3). Race and histories: Examining culturally relevant teaching in the U.S. history classroom. Theory \& Research in Social Education, $4 \mathrm{I}(\mathrm{I}), 65-88$. http://dx.doi.org/IO.I 080/00933104.2013.755745

McCully, A. (20I0). What role for history teaching in the transitional justice process in deeply divided societies? In I. Nakou \& I. Barca (Eds.), Contemporary public debates over history education: A volume in International Review of History Education (pp. 169-184). Charlotte, NC: Information Age Publishing.

McGregor, H. (2013). Is teaching history "for social justice" working well for indigenous students? [Weblog]. Retrieved from http://thenhier.ca/en/content/blog-contest-teachinghistory-\%E2\%80\% $\%$ C-social-justice $\% \mathrm{E} 2 \% 80 \% 9 \mathrm{D}$-workingwell-indigenous-students

Ministry of Education. (2011). Tãtaiako: Cultural competencies for teachers of Mãori learners. Wellington: Author. Retrieved from http://www.teacherscouncil.govt.nz/required/tataiako.stm.

New Zealand Qualifications Authority (NZQA). Annual Report on NCEA and New Zealand Scholarship data and statistics (20I2). Retrieved from http://www.nzqa.govt.nz/assets/Aboutus/Publications/stats-reports/ncea-annualreport-20I2.pdf

Keown, P. (1998). Values and social action: Doing the hard bits. In P. Benson \& R. Openshaw (Eds.), New horizons for New Zealand social studies (pp. 137-159). Palmerston North: ERDC Press.

Otago Daily Times. (2010, June 23). Maori history avoided in schools. Otago Daily Times. Retrieved from http://www.odt. co.nz/news/national/ıı210o/maori-history-avoided-schoolsacademics

Peck, C. L. (20Io). "It's not like [I'm] Chinese and Canadian. I am in between": Ethnicity and students' conceptions of historical significance. Theory and Research in Social Education, 38(4), 574-617. http://dx.doi.org/I0.1080/00933104.2010.104734 40

Peck, C. L., Poyntz, S., \& Seixas, P. (20II). "Agency" in students' narratives of Canadian history. In D. Shemilt \& L. Perikleous (Eds.), The future of the past: Why history education matters (pp. 253-280). Nicosia, Cyprus: Association for Historical Dialogue and Research.

Penetito, W. (2009). Place-based education: Catering for curriculum, culture and community. New Zealand Annual Review of Education, I8, 5-29. 


\section{HE WHAKAARO ANO}

Reymer, C. (2012). Have you asked your students? Pasifika perspectives on studying history. In M. Harcourt \& \& M. Sheehan, History matters: Teaching and learning history in New Zealand secondary schools in the $2 I^{\text {st }}$ century. Wellington: NZCER Press.

Salmond, A. (2006) Ancestral places. In K. Gentry \& G. Mclean (Eds.), Heartlands: New Zealand historians write about where history happened (pp. I35-I44). Auckland: Penguin Books.

Scherff, L. \& Spector, K. (20I0). Culturally relevant pedagogy: Clashes and confrontations. Plymouth: Rowman \& Littlefield Education.

Seixas, P., \& Morton, T. (2012) The big six: Historical thinking concepts. Toronto: Nelson Publishers.

Sheppard, M. (20IO). Creating a caring classroom in which to teach difficult histories. The History Teacher, 43(3), 4II-26.

Shields. C., Bishop. R., Mazawi, A. (2004). Pathologizing practices: The impact of deficit theorizing on education, New York: Peter Lang Publishing.

Tamua, M. (20I4). Te takanga o te wä-Mãori history in Aotearoa New Zealand: Teaching guidelines for years $I-4$. Retrieved from http://maorihistory.tki.org.nz/assets/ Uploads/Te-Takanga-o-Te-Wa.pdf

Traille, K. (2007). "You should be proud about your history. They make me feel ashamed": Teaching history hurts. Teaching History, I27, 3I-37.

Trouillot, M.R. (1995). Silencing the past: Power and the production of history. Boston, MA: Beacon Press.
Webber, M. (2013). Student ethnicity. set: Research information for Teachers, $1,67-70$.

Webber, M. (20I2). Identity matters: Racial-ethnic identity and Māori students. set: Research information for Teachers, 2, 20-27.

Wessels, T. (1997). Reading the landscape. In C. Leslie, J. Tallmadge, \& T. Wessels (Eds.), Into the field: A guide to locally focused teaching, (pp.59-8I). Barrington, MA: The Orion Society.

Wood, B. E. (2007). Conflict, controversy, and complexity: Avoiding the 'slippery stuff' in social studies. Critical Literacy: Theories and Practices, I(2), 42-49.

Wrenn, A. (2007). Teaching emotive and controversial history. London, England: The Historical Association.

Michael Harcourt is a history and social studies teacher at Wellington High School. He is the co-editor of the book History Matters: Teaching and Learning History in New Zealand Secondary Schools in the 21st Century. Michael was the 2015 recipient of the FulbrightCognition Scholar Award in Education Research.

Email: michael.harcourt@whs.school.nz. 